niego znacznie wcześniej. W rozdziale poświęconym Diderotowi autor odwołuje się do Helwecjusza, który jest omówiony dopiero parę stron później. Wątpliwości budzą niektóre definicje przyjęte przez autora, np. że „ontologia określa cel życia człowieka” [s. 28] - to bardziej czyni normatywna etyka lub antropologia filozoficzna, niż ontologia zajmująca się opisem bytu metafizycznego. Jeszcze jedną moją uwagą krytyczną wobec podręcznika Kupisiewicza jest wysoki europocentryzm tej pozycji. Skoro bowiem mowa o powszechnej syntezie poglądów na wychowanie w dziejach - dlaczego nie znalazły się tu krótkie chociaż rozdziały na temat edukacji w mandaryńskiej kulturze chińskiej, czy kastowym systemie braminów w Indiach?

Wszystkie te powyższe zarzuty nie mają jednak charakteru pierwszorzędnego ani nie deprecjonują wysokich walorów dydaktycznych i akademickich recenzowanej publikacji. Można ją z czystym sumieniem polecić wszystkim osobom zainteresowanym nie tylko pedagogika, ale przede wszystkim bogatą historią wychowania w kulturze zachodniej. Zaryzykuję nawet twierdzenie, że jest to pozycja obowiązkowa na półce każdego polskiego inteligenta, pretendującego do erudycji humanistycznej.

Juliusz Iwanicki

\title{
Dorota Żołądź-Strzelczyk, Katarzyna Kabacińska-łuczak, Codzienność dziecięca opisana slowem i obrazem. Życie dziecka na ziemiach polskich od XVI do XVIII wieku, Wydawnictwo DiG, Warszawa 2012, ss. 190
}

W ostatnich dekadach problematyka dziecka i dzieciństwa stała się przedmiotem analiz i badań naukowców z wielu dziedzin, czego wynikiem są liczne opracowania o charakterze historycznym, pedagogicznym, historyczno-pedagogicznym, socjologicznym, etnograficznym, antropologicznym, filozoficznym. Ta wielość spojrzeń na wskazane problemy pozwala na odnalezienie różnorodnych sposobów rozumienia dziecka i dzieciństwa, wskazanie różnych modeli dzieciństwa zarówno w minionej przeszłości, jak i współcześnie.

Jedną z najnowszych prac poświęconych dziecku w ujęciu historyczno-pedagogicznym jest praca autorstwa Doroty Żołądź-Strzelczyk i Katarzyny Kabacińskiej, które przedmiotem swych badań uczyniły codzienność dziecięcą na ziemiach polskich od XVI do XVIII w. Autorki ukazują czytelnikowi świat dzieciństwa, charakteryzując warunki, miejsca i przestrzeń funkcjonowania dzieci, elementy kultury materialnej związanej z dziećmi w różnych przedziałach wiekowych i różnych stanach, tworząc tym samym niezwykle interesujący, barwny i stosunkowo wszechstronny obraz życia najmłodszych członków społeczeństwa na ziemiach polskich okresu przedrozbiorowego. Warto w tym miejscu podkreślić, że publikacja stanowi swoistą kontynuację prowadzonych wcześniej przez Dorotę Żołądź-Strzelczyk badań nad dzieckiem i dzieciństwem doby staropolskiej, których wyniki zamieszone zostały w pracy Dziecko w dawnej Polsce (Poznań 2002, 2006). W charakteryzowanej pracy cześć prezentowanych wcześniej treści została zna- 
cząco uszczegółowiona, rozszerzona i zdecydowanie pogłębiona, dzięki wynikom uzyskanym z analiz materiału ikonograficznego, a także podana w zdecydowanie bardziej atrakcyjnej formie połączenia słowa pisanego i obrazu.

Szczególnym atutem pracy jest wykorzystanie do badań materiałów ikonograficznych, głównie o charakterze sakralnym, które w większości zgromadzone zostały w kościołach i klasztorach w całej Polsce. Docenić należy rezultaty kilkuletnich poszukiwań i analiz źródłowych materiału ikonograficznego, najczęściej dotąd nieznanego, niedostępnego szerszej publiczności i niepublikowanego, który dzięki Autorkom nie tylko ujrzał światło dzienne, ale zdecydowanie wzbogacił postrzeganie i rozumienie świata dziecięcego badanego okresu. Źródła ikonograficzne najczęściej do tej pory wykorzystywane są w pracach historyczno-pedagogicznych jako materiał ilustracyjny, będący uzupełnieniem źródeł pisanych. W tej pracy jednak Autorki uczyniły z nich równorzędne źródło i podstawę do uzyskania wiedzy o dzieciństwie na ziemiach polskich do końca I Rzeczypospolitej. I choć codzienność dziecięca stosunkowo rzadko pojawiała się w staropolskich przedstawieniach ikonograficznych, to Autorkom, na podstawie zgromadzonego materiału udało się odtworzyć różnorakie jej aspekty, począwszy od narodzin po cudowne uzdrowienia. Podkreślić należy, że wykorzystana w pracy metoda ikonograficzna polega nie tyle na prezentacji materiału ikonograficznego, ile na jego analizie jako źródła historycznego - na próbie odczytania treści jego przekazu. Jak więc widać na przykładzie charakteryzowanej pozycji, warto na potrzeby badań nad dzieckiem i dzieciństwem czy edukacją poszukiwać, gromadzić i analizować źródła ikonograficzne, mogą one bowiem w cenny sposób wzbogacić wiedzę z danego okresu historycznego, stanowiąc ważny i bardzo interesujący dla odbiorcy sposób przedstawienia wydarzeń historycznych i faktów związanych z badaną problematyką. Materiały ikonograficzne są bowiem nie tylko dziełami sztuki, ale stanowią wartościowy, a nader rzadko (żeby nie powiedzieć niemal wcale) wykorzystywany nośnik informacji, cennych z punktu widzenia badań historycznych czy, jak w prezentowanym przypadku, historyczno-pedagogicznych. Źródła ikonograficzne - m.in. wykorzystane w tej pracy obrazy czy malowidła, ale i rzeźby, ryciny, drzeworyty, rysunki, karykatury, szkice, fotografie, pozwalają zatrzymać czas przekazując nam obraz tego, co działo się w jakimś momencie historii, ukazując, jak wyglądała codzienność i życie ludzi danej epoki, także dzieci. Pozwalają one przyjrzeć się, jak w minionych wiekach wyglądały stroje, wnętrza mieszkalne, przedmioty użytkowe - także adresowane dla najmłodszych, dla nich i na ich potrzeby wykonywane i przez nich wykorzystywane. Źródła ikonograficzne pozwalają badaczowi nie tylko stwierdzić, jak wyglądało, ale i jak zmieniało się życie i funkcjonowanie rodzin polskich w minionych wiekach, w tym także ich najmłodszych członków, których uczyniono przedmiotem badań opisywanej pozycji.

$\mathrm{Na}$ uwagę i podkreślenie zasługuje fakt, że dokonane w pracy analizy są rzetelne i szczegółowe, gdyż obok głównego źródła, jakim uczyniono wskazane materiały ikonograficzne, oparte zostały na różnorodnych źródłach pisanych, których zgromadzenie, jak piszą same Autorki, nastręczało wiele trudności z powodów niewielkiej ich liczby w badanym okresie. Wykorzystano tu m.in.: kroniki, pisma pedagogiczne, wspomnienia i pamiętniki, instrukcje rodzicielskie, roczniki, literaturę poradnikową, inwentarze miesz- 
czańskie, listy, poezje. Dzięki analizom źródeł ikonograficznych odtworzona została głównie materialna strona codzienności dziecięcej od XVI do XVIII w., uzupełniona przez różnorodne przekazy pisane, dopełniające i wzbogacające dane uzyskane $\mathrm{z}$ analiz ikonografii. Podejmowane w pracy problemy opisano więc, jak podkreślono już w tytule pracy - „słowem i obrazem”. Dzięki temu praca ma bogate walory poznawcze i jest atrakcyjna dla odbiorcy - zarówno w sferze faktograficznej, jak i wizualnej. Tak skonstruowana publikacja stanowi z pewnością pierwszy na polskim rynku wydawniczym i jedyny w swoim rodzaju zbiór informacji poświęconych codzienności dziecięcej okresu przedrozbiorowego, a ich charakterystyka w oparciu (obok tradycyjnie wykorzystywanych źródeł pisanych) o źródła ikonograficzne pozwoliła stworzyć swoisty album polskiej sztuki (głównie sakralnej), poświęconej dziecku i dzieciństwu. Praca wypełnia więc w sposób znaczący lukę w polskiej historiografii dotyczącej problematyki dziecka i dzieciństwa minionych wieków.

Charakteryzowana pozycja ma charakter problemowy. Składa się z 6 rozdziałów, z których każdy dzieli się na szczegółowe podrozdziały, wnikliwie i szczegółowo analizujące podejmowane zagadnienie. Wszystkie rozpatrywane problemy zilustrowane zostały materiałem ikonograficznym, służącym do prowadzonych analiz. Warto w tym miejscu krótko przybliżyć treść publikacji, ze wskazaniem na poruszane w niej kluczowe zagadnienia.

Pierwszy rozdział poświęcony został początkowi życia ludzkiego - narodzinom i okresowi niemowlęcemu. Analizując głównie ikonografię religijną, np. sceny z narodzin Maryi opisano warunki przyjścia dziecka na świat - izbę, w której odbywał się poród, łoże dla rodzącej, kołyskę przygotowaną dla nowo narodzonego dziecka, osoby towarzyszące położnicy i dziecku - położne, mamki i piastunki. Scharakteryzowano też zwyczaj wywodu następujący po sześciotygodniowym okresie izolacji matki i dziecka. Sporo uwagi Autorki poświęciły kąpieli niemowląt, która miała znaczenie zarówno higieniczne, jak i magiczne, opisując sprzęty niezbędne do jej przeprowadzenia, zioła dodawane do wody, materiały do powijania. Powijakom zresztą autorki poświęcają osobny z podrozdziałów, podobnie jak kołyskom, ukazując je zarówno w scenach prezentowanych na obrazach, jaki i przywołując opisujące je teksty z epoki. Kolejnym zagadnieniem W części poświęconej niemowlęciu jest karmienie - zgodnie z zaleceniami staropolskimi - piersią matczyną. Rozdział pierwszy zamyka „charakterystyka prawdziwego początku życia dziecka" (s. 43) - chrztu świętego.

W rozdziale drugim przedstawione zostały wybrane aspekty życia i funkcjonowania dziecka w rodzinie. Skupiono się na problematyce dzietności, znajdującej swoje odzwierciedlenie również w źródłach ikonograficznych, relacjach pomiędzy rodzicami a dziećmi, znaczeniu przykładu rodziców w wychowaniu dzieci, atmosferze domu rodzinnego, zaangażowaniu rodziców w wychowanie, ich stosunku do śmierci potomka.

Trzeci, najobszerniejszy rozdział, dotyczy charakterystyki strojów dziecięcych, które zróżnicowane były w zależności od płci, wieku, a przede wszystkim pochodzenia dziecka. Inaczej ubierano dzieci królewskie (i tym Autorki poświęcają osobny podrozdział), inaczej szlacheckie, mieszczańskie czy z warstw najuboższych (choć tym poświęcono najmniej miejsca, z powodu braku przekazów źródłowych). Autorki przywołują zalece- 
nia teoretyków dotyczące strojów dziecięcych, a także rozlegle piszą o poszczególnych ich elementach: specjalnych paskach do nauki chodzenia, czapkach chroniących głowę przed upadkiem (rzadko spotykanych na ternie ziem polskich), dziecinnych koszulkach, dziewczęcych sukienkach, fartuszkach, czepeczkach, sukienkach, kaftanikach, pończoszkach, bucikach, a nawet habitach, zarówno prostych i skromnych, jak i bogato zdobionych. Opisując stroje chłopięce wskazują na żupany, kontusze, spodnie, koszule, czapki, pończochy. Wszystkie opisane elementy garderoby czytelnik może oczywiście obejrzeć na załączonych materiałach ikonograficznych - fragmentach portretów dziecięcych, obrazów, epitafiów, portretów trumiennych. Ich analiza powala także dostrzec przemiany, jakie zachodziły w stroju dziecięcym, zgodnie ze zmieniającym się kanonem mody doby staropolskiej, nawiązującej głównie do mody zachodnioeuropejskiej, a także tradycyjne stroje polskie.

Czwartą cześć charakteryzowanej pracy Autorki poświęciły specjalnie dla dzieci robionym i przez nie wykorzystywanym sprzętom - dziecinnym łożom i łóżeczkom, bieliźnie pościelowej, krzesełkom i stolikom, chodzikom do nauki chodzenia, przedmiotom służącym higienie - nocnikom, wanienkom, miednicom, dzbanom na wodę. Opisano też sprzęty służące do karmienia dzieci - poidełka, butelki, miseczki, łyżeczki. Skupiono się także na przestrzeni, jaka przysługiwała dzieciom z różnych warstw społecznych (w chatach, dworach, kamienicach czy pałacach) i warunkach ich funkcjonowania.

W rozdziale piątym Autorki połączyły problematykę zabawy i edukacji dziecka, argumentując tę decyzję wzajemnym przenikaniem się obu sfer, wypełniających znaczną część życia dziecka. Czytelnik ma okazję poznać popularne w analizowanym okresie zabawy dziecięce, głównie ruchowe i zespołowe, ale i zabawy dla najmłodszych (niemowląt i dzieci), jak i młodzieży. Nie zabrakło także informacji o przedmiotach służących zabawom - zabawkach, w tym grzechotkach dla niemowlatt, figurkach zwierzatt, bąkach, lalkach, konikach na kijach, piłkach, rakietach do wolanta, kółkach do serso. Tu warto nadmienić, że rozdział ten stanowi kontynuację i uszczegółowienie prowadzonych wcześniej przez Autorki badań nad problematyką zabaw i zabawek dziecięcych, również w oparciu o źródła pisane i ikonograficzne, które zaprezentowane zostały w albumie Dawne zabawy dziecięce (Kielce-Warszawa 2008). Osobne rozważania poświęcone zostały edukacji dzieci zarówno domowej jak i szkolnej, z uwzględnieniem zapatrywań teoretycznych dotyczących problematyki kształcenia, jak i ich odzwierciedleniach na staropolskiej ikonografii, niezbyt niestety bogatej w tym zakresie.

Rozdział zamykający prace poświęcono zabiegom będącym wyrazem troski o zdrowie i życie dzieci, sposobom radzenia sobie rodziców i bliskich w sytuacji ich choroby i śmierci. Było to najczęściej oddawanie dzieci w opiekę świętych z nadzieją na uzdrowienie. Autorki sięgnęły do rzadko wykorzystywanych źródeł, jakimi są opisy cudów związanych z najmłodszymi zarówno narracyjne, jak i ikonograficzne. Ratunku u świętych szukano w wielu sytuacjach - od bezdzietności, przez szczę́liwy poród, ratowanie ciężarnych z opresji i wypadków, przedwczesne narodziny, narodziny martwych niemowląt. Wstawiennictwo świętych, liczne modlitwy, pielgrzymki, odwiedziny miejsc cudownych miały sprawiać cuda i ratować dzieci chore, słabowite, umierające, ofiary wypadków losowych. Po dokonanych uzdrowieniach często pozostawały dary wotywne, w tym obrazy, które autorki wykorzystują do analiz i zamieszczają w rozdziale. 
Na końcu pracy czytelnik zainteresowany bliżej prezentowaną problematyką znajdzie bogatą bibliografię - zarówno źródeł pisanych wykorzystanych do badań, jak i opracowań poświęconych problematyce dziecka i dzieciństwa minionych wieków (ze szczególnym uwzględnieniem okresu staropolskiego), historii sztuki, metodologii badań historycznych itp. W wykazie fotografii dokładnie opisano 185 zdjęć materiałów ikonograficznych (głównie malarstwa), z podaniem, obok prezentowanego problemu - tytułu dzieła, z którego został zaczerpnięty, miejsca i miejscowości, w których praca się znajduje, a także przypuszczalnej daty jego powstania. Dołączony do publikacji indeks nazwisk osób oraz miejscowości pozwoli odnaleźć interesującą czytelnika postać czy miejsce bez konieczności analizy całości treści stosunkowo obszernej publikacji.

Język, jakim posługują się Autorki jest jasny, prosty i zrozumiały dla przeciętnego czytelnika, co niewątpliwie jest ważną zaletą każdej pracy naukowej. Narracja została tak skonstruowana, że prezentowane wyniki badań, formułowane uogólnienia i wnioski pochodzące $\mathrm{z}$ analizy materiałów ikonograficznych uzupełnianie są fragmentami cytatów źródeł pisanych. Powoływanie się na teksty pisane językiem okresu, którego dotyczą badania, oddaje specyficzny klimat epoki i zdecydowanie uatrakcyjnia odbiór tekstu. Autorki z pewnością miały tego świadomość, gdyż konstruując spis treści wykorzystały fragmenty tekstów z epoki, co czyni tytuły rozdziałów oryginalnymi i zachęcającymi do lektury.

Na uwagę zasługuje także niezwykle atrakcyjny dla czytelnika sposób wydania publikacji: twarda oprawa, wysokogatunkowy papier, kolorowe, wysokiej jakości rekonstrukcje źródeł ikonograficznych z pewnością uczynią tę pozycję ,perełką” niejednej biblioteki.

Prezentowana książka z całą pewnością będzie ciekawą lekturą dla czytelnika zainteresowanego dziejami dziecka i dzieciństwa, a także dla każdego, kto zechce poznać codzienność i życie prywatne okresu przedrozbiorowego. Może zostać z powodzeniem wykorzystana jako podręcznik dla studentów podczas zajęć z historii dziecka i dzieciństwa, filozofii dzieciństwa, historii myśli pedagogicznej, historii wychowania w rodzinie itp. na studiach pedagogicznych, a także na innych kierunkach, gdzie na zajęciach podejmuje się problematykę dzieciństwa, np. psychologii, antropologii, kulturoznawstwa, filozofii, socjologii itp. Książka nie tylko dostarcza ważnych i ciekawie ujętych problemów, które z pewnością zainteresują studentów, ale może też inspirować do analizy zbliżonej tematyki podczas pisania prac licencjackich czy magisterskich. Być może lektura tej książki stanie się też inspiracją dla innych naukowców i zachęci do podejmowania kolejnych badań historyczno-pedagogicznych (i nie tylko) z wykorzystaniem materiału ikonograficznego jako głównego i niezwykle wartościowego źródła analiz.

Zdecydowanie warto zachęcić czytelników do sięgnięcia po tę zupełnie inną niż dotąd pozycję poświęconą dziecku i dzieciństwu okresu staropolskiego - barwną nie tylko z powodu interesujących i wartościowych ustaleń historiograficznych, ale także z powodu bogatej i rzadko dotąd wykorzystywanej, a będącej ich podstawa, warstwy ikonograficznej.

Monika Nawrot-Borowska 